\title{
PENGARUH UPAH DAN INSENTIF KARYAWAN TERHADAP KINERJA KARYAWAN PADA PT. MILANO PANAI TENGAH
}

\author{
Ruslan Efendi, Junita Lubis, Elvina \\ Prodi Manajemen, Fakultas Ekonomi dan Bisnis, Universitas Labuhanbatu \\ Email : junitayuri@yahoo.com
}

\begin{abstract}
ABSTRAK
Penelitian ini bertujuan untuk mengetahui bagaimana pengaruh upah dan insentif terhadap kinerja karyawan PT Milano Panai Tengah. Penelitian ini menggunakan metode pengumpulaan data dengan menyebarkan kuesioner. Populasi dan sample yang digunakan dalam penelitian ini adalah karyawan di PT Milano Panai Tengah sebanyak 57 responden. Pengujian hipotesis dalam penelitian ini menggunakan alat analisis uji validitas, uji realibilitas, uji asumsi klasik regresi linier berganda, (uji t), ( uji F), dan koefesien determinasi $\left(\mathrm{R}^{2}\right)$. Hasil penelitian ini menunjukkkan bahwa secara parsial (uji t) upah dan berpengaruh positif dan signifikan terhadap kinerja karyawan. dengan t hitung sebesar 3.415. Insentif berpengaruh positif dan signifikan terhadap Kinerja dengan t hitung sebesar 6.758. Secara simultan upah dan insentif secara bersama-sama berpengaruh positif dan signifikan terhadap kinerja, dengan $\mathrm{F}$ hitung sebesar 50.377. Melalui pengujian koefisien determinasi (R Square) sebesar 0,652 atau 65.2\% yang menunjukkan bahwa kinerja dijelaskan oleh upah dan insentif selebihnya sebesar $34.8 \%$ dijelaskan oleh variabel lain yang tidak termasuk dalam penelitian ini.
\end{abstract}

Kata kunci : Upah, Insentif, Kinerja guru

\section{ABSTRACT}

This study aims to determine how the influence of wages and incentives on performance at PT Perkebunan Milano. This study uses data collection methods by distributing questionnaires. The population and sample used in this study were 57 employees of PT Perkebunan Milano. Hypothesis testing in this study uses a validity test analysis tool, reliability test, the classic assumption test of multiple linear regression, ( $t$ test), ( $F$ test), and the coefficient of determination (R2). The results of this study indicate that there is a positive influence The results of this study indicate that partially ( $t$ test) wages and a positive and significant effect on employee performance. with a t count of 2,422. Incentives have a positive and significant effect on performance with t count of 6.114. Simultaneously wages and incentives together have a positive and significant effect on performance, with an $F$ count of 22,458. Through testing the coefficient of determination ( $R$ Square) of 0.454 or $45.4 \%$ which shows that the performance is explained by wages and the remaining incentives of $54.6 \%$ are explained by other variables not included in this study.

Keywords: Wages, Incentives, Employee Performance 


\section{LATAR BELAKANG MASALAH}

Sumber daya manusia adalah suatu ilmu atau cara bagaimana mengatur hubungan dan peran sumber daya (tenaga kerja) yang dimiliki oleh individu secara efektif dan efesien serta dapat digunakan dapat digunakan secara maksimal sehingga tercapai tujuan bersama, karyawan dan masyarakat menjadi maksimal. Tanpa sumber daya manusia yang baik, semua kegiatan suatu organisasi tidak dapat berjalan sesuai dengan rencana atau tujuan perusahaan. Suatu organisasi dapat berkembang dengan baik apabila terdapat sumber daya manusia yang menghasilkan kinerja yang berkualitas dan bertingkah baik.

Sebaliknya apabila sumber daya manusia yang dimililki perusahaan tersebut tidak dapat memberikan kinerja yang berkualitas dan bertingkah laku yang buruk maka dapat membuat organisasi tersebut menjadi hancur. Hal ini menunjukan bahwa sumber daya manusia merupakan hal yang penting harus di perhatikan dengan segala hal kebutuhanya. Sumber daya manusia merupakan suatu sarana untuk memperbaiki serta meningkatkan kinerja (performance) dan daya hasil perusahaan.

Kinerja guru mempengaruhi seberapa besar guru tersebut memberikan kontribusi kepada sekolah. Kinerja mempengaruhi hasil atau tujuan sekolah jika kinerja buruk maka tujuan sekolah tidak dapat tercapai. Begitu juga sebaliknya maka dari itu setiap sekolah memiliki tata cara penilaian yang berbeda-beda di setiap sekolah.

Kinerja guru juga dipengaruhi oleh tingkat upah tingkat upah adalah jumlah uang yang dibayarkan oleh pihak sekolah kepada para pekerjanya atas hasil kinerja yang telah dilakukan untuk kelangsungan hidup sekolah dalam periode waktu tertentu. Dalam menentukan tingkat upah, suatu organisasi harus dapat mengetahui bagaimana cara menentukan upah diberbagai jenis pasar kemudian suatu organisasi harus dapat mengetahui seberapa besar hubungan tingkat kinerja, insentif, serta menentukan tingkat upah nominal bagi para pekerjanya. Manusia sebagai makhluk individu mempunyai bermacam-macam kebutuhan yang harus dipenuhi.

Berbagai jenis kebutuhan tersebut diantaranya dapat dicapai melalui pengabdian kepada organisasi tempat mereka bekerja dengan adanya imbalan atau kompensasi dalam bentuk uang yang disebut upah. Upah merupakan dorongan utama seseorang untuk bekerja, karena dengan adanya upah yang diperoleh sebagai realisasidari jasa yang telah mereka berikan, mereka dapat mencukupi berbagai kebutuhannya.Apabila tingkat upah yang ditawarkan meningkat maka kinerja pekerja jugaakan meningkat setiap tahunnya serta dapat menyebabkan peningkatan jumlah upah minimum. Suatu organisasi perlu pemberian perhatian yang lebih terhadap keberadaan karyawan agar loyalitas karyawan terhadap keberadaan juga tinggi. Sebaiknya suatu organisasi juga perlu mengetahui latar belakang penyebab menurunnya kinerja karyawan Salah satunya adalah masalah upah karyawan.

Dalam pemberian upah, suatu organisasi harus memperhatikan prinsip keadilan. Faktor lain yang juga perlu diperhatikan mengenai masalah upah adalah kelayakan. Dalam pemberian upah perlu diperhatikan apakah upah tersebut telah mencukupi kebutuhan minimal. Selain itu faktor upah dan gaji ikut mempengaruhi baik tidaknya kinerja karyawan. Upah sebagai salah satu komponen kompensasi memegang peranan penting dalam upaya meningkatkan kepuasan kerja karyawan. Upah bagi sebagian karyawan merupakan faktor perangsang dalam 
mendorong karyawan mencapai tujuannya sehinga pemberian upah yang layak bagi karyawan harus diperhatikan. Upah yang diberikan dengan benar dapat menyebabkan karyawan merasa terpuaskan dan termotivasi untuk mencapai tujuan.

Insentif berpengaruh terhadap kinerja karyawan sedangkan karyawan sangat berperan penting dalam meningkatkan atau mencapai tujuan perusahaan, maka pemberian insentif yang memadai karyawan perlu mendapatkan perhatian khusus sehingga dapat melaksanakan tugasnyadan dapat mengembangkan kemampuan mereka semaksimal mungkin. Insentif sangat diperlukan memacu kinerja para karyawan agar selalu berada pada tingkat tertinggi sesuai kemampuan masing-masing. Peran insentif cukup besar dalam membentuk karyawan potensial Insentif merupakan salah satu bentuk pemberian diluar upah. penghargaan yang di berikan kepada karyawan terkait dengan dengan kontribusi karyawan dalam pencapaian tujuan perusahaan.

Kurang maksimalnya kinerja dari karyawan pada PT. Perkebunan Milano, antara lain dapat terlihat dari rendahnya motivasi untuk berprestasi yang ditunjukkan oleh beberapa karyawan yang bekerja hanya kalau ada tugas dari pimpinan atau perusahaan, mereka tidak secara mandiri menyelesaikan pekerjaan dengan baik dan cepat. Keadaan seperti ini menyebabkan pelaksanaan pekerjaan kebanyakan dilakukan oleh orang tertentu saja yaitu karyawan yang berhadapan langsung dengan bidang tugas dan wewenangnya. Permasalahanpermasalahan tersebut. mencerminkan bahwa masih diperlukan adanya upaya untuk mencapai peningkatan kinerja karyawan yang antara lain dipengaruhi oleh pemberian upah dan insentif kepada karyawan yang dapat menyelesaikan pekerjaan dengan baik dan cepat.

Perumusan Masalah

Berdasarkan latar belakang masalah, maka perumusan masalah dalam penelitian ini dirumuskan sebagai berikut:

1. Apakah upah berpengaruh signifikan terhadap kinerja karyawan di PT. Milano Panai Tengah?

2. Apakah insentif berpengaruh signifikan terhadap kinerja karyawan di PT. Milano Panai Tengah?

3. Apakah upah dan insentif berpengaruh signifikan terhadap Kinerja karyawan di PT. Milano Panai Tengah?

\section{Tujuan Penelitian}

Tujuan yang ingin dicapai dalam penelitian ini adalah:

1. Untuk mengetahui pengaruh upah terhadap Kinerja karyawan di PT. Milano Panai Tengah

2. Untuk mengetahui pengaruh Insentif terhadap kinerja karyawan di PT. Milano Panai Tengah

3. Untuk mengetahui pengaruh upah dan Insentif karyawan terhadap Kinerja karyawan di PT. Milano Panai Tengah

\section{Manfaat Penelitian}

1. Bagi STIE Labuhanbatu

Menambah referensi bagi perpustakaan STIE Labuhanbatu sebagai wacana dalam melakukan penelitian bagi mahasiswa di masa yang akan datang.

2. Bagi Perusahaan

Bagi Perusahaan sebagai bahan masukan dan referensi mengenai Pengaruh Upah dan Insentif terhadap Kinerja Karyawan sehingga dapat menjadi pertimbangan untuk 
mengambil kebijakan atau keputusan yang dipandang perlu dalam usaha meningkatkan kinerja karyawan.

1. Bagi Penulis

Penelitian ini diharapkan dapat memperluas pengetahuan peneliti memberikan informasi,wawasan, dan pengalaman secara langsung tentang ekonomi manajemen sumber daya manusia, khususnya mengenai khususnya mengenai Pengaru Upah dan Insentif terhadap Kinerja Karyawan pada PT Perkebunan Milano Panai Tengah.

4. Bagi Peneliti Lain

Sebagai bahan referensi dan wacana yang nantinya dapat memberikan perbandingan dalam melakukan penelitian lebih lanjut.

\section{LANDASAN TEORI}

\section{Upah}

Upah adalah imbalan jasa atau uang yang dibayarkan, atau yang ditentukan untuk dibayarkan kepada seseorang pada jarak-jarak waktu yang teratur untuk jasa-jasa yang diberikan. Upah merupakan faktor yang dominan yang memungkinkan seseorang bersedia bekerja untuk kepentingan orang lain atau untuk perusahaan ataupun organisasi. Tanpa upah tidak akan ada pengertian hubungan kerja antara tenaga kerja dengan organisasi ataupun perusahaan. Sehingga dalam sebuah organisasai ataupun perusahaan, upah merupakan suatu hal yang sangat penting.

Upah sangat besar pengaruhnya terhadap tenaga kerja dalam menjalankan tugasnya dan jaminan terhadap kelangsungan hidup dirinya sendiri dan keluarganya. Memberikan upah yang rendah akan menimbulkan kesulitan dalam perekrutan dan memperkerjakan tenaga kerja yang profesional. Namun jika upah yang diberikan kepada tenagakerja sesuai dengan pekerjaan yang dilakukannya, maka para tenaga kerja akan bekerja semaksimal mungkin kepada perusahaan.

Menurut oleh Edwin B. Flippo ( dalam Justine T. Sirait, 2010:23) menyatakan bahwa upah merupakan harga untuk jasa-jasa yang telah diberikan seseorang kepada orang lain. upah merupakan suatu penerimaan sebagai imbalan dari pimpinan perusahaan kepada tenaga kerja untuk suatu pekerjaan atau jasa yang telah dan akan dilakukan. Adapun indikator dari upah yaitu : Sistem pengupahan, sistem upah menurut produksi, sistem upah menurut senioritas dan sistem upah menurut kebutuhan.

Menurut Justine T. Sirait (2010:181), Upah berfungsi sebagai keberlangsungan hidup yang layak bagi kemanusiaan dan produksi yang dinyatakan dalam bentuk uang yang ditetapkan menurut suatu persetujuan, undang-undang, peraturan, dan dibayarkan atas suatu dasar perjanjian kerja antara pemimpin perusahaan dengan tenagakerja.Menurut Menteri Tenaga Kerja dan Transmigrasi RI No. KEP - 49/MEN/IV/2007 tentang ketentuan skala upah

Upah adalah hak pekerja atau buruh yang diterima dan dinyatakan dalam bentuk uang sebagai imbalan dari pengusaha atau pemberi kerja kepada pekerja atau buruh yang ditetapkan dan dibayarkan menurut suatu perjanjian kerja, kesepakatan atau peraturan perundangundangan termasuk tunjangan bagi pekerja atau buruh dan keluarganya atas suatu pekerjaan dan jasa yang telah atau akan dilakukan 
Dari pengertian-pengertian tentang upah, maka dapat disimpulkan bahwa upah adalah imbalan financial lansung dibayarkan kepada tenaga kerja berdasarkan jam kerja, jumlah barang yang dihasilkan atau banyaknya pelayanan yang dihasilkan.

\section{a. Proses Penentuan Upah}

Salah satu aspek yang sangat penting dalam penentuan upah adalah jumlah upah yang diterima tenaga kerja harus memiliki internal equity dan external equity. Internal equity adalah jumlah yang diperoleh dipersepsi sesuai dengan input yang diberikan dibandingkan dengan pekerjaan yang sama dalam perusahaan. External equity adalah jumlah yang diterima dipersepsi sesuai dengan jumlah yang diterima dipekerjaan lain organisasi atau perusahaan. Menurut Veithzal Rivai dan Jauvani Sagala (2010:759-761) untuk mengusahakan adanya equity maka penentuan upah dalam perusahaan dapat ditempuh dengan:

\section{1) Analisis jabatan atau tugas}

Analisis jabatan adalah kegiatan mencari informasi tentang tugas-tugas yang dijalankan dan persyaratan yang diperlukandalammelaksanakan tugasnya, sehingga dapat menjelaskan uraian tugas dan standar kinerja.

2) Evaluasi jabatan atau tugas

Evaluasi jabatan merupakan proses sistematis untuk menentukan nilai relatif dari suatu pekerjaan dengan pekerjaan lain.Proses ini merupakan usaha supaya tercapai internal equity dalam pekerjaan sebagai unsur dalam menetapkan tingkat upah.

3) Survei upah

Survei upah adalah kegiatan untuk mengetahui tingkat upah yang berlaku pada perusahaanperusahaan yang lain yang sejenis, yang mempunyai usaha atau jabatan yang sama. Kegiatan ini dilakukan supaya terjadi keadilan eksternal sebagai salah satu faktor terpenting dalam menentukan upah.

4) Penentuan upah

Penentuan upah berdasarkan hasil evaluasi jabatan yang dikombinasikan dengan survei upah yang terpenting dalam penentuan upah adalah sesuai dengan tingkat upah minimum yang telah ditetapkan oleh pemerintah

\section{Insentif}

Insentif adalah merupakan balas jasa yang diberikan oleh perusahaan yang dapat dinilai dengan uang dan mempunyai kecenderungan diberikan secara tetap. Insentif diartikan sebagai bentuk pembayaran yang dikaitkan dengan kinerja dan gainsharing, sebagai pembagian keuntungan bagi karyawan akibat peningkatan produktivitas atau penghematan biaya. Sistem ini merupakan bentuk lain dari kompensasi langsung di luar gaji dan upah yang merupakan kompensasi tetap, yang disebut sistem kompensasi berdasarkan kinerja.Insentif merupakan faktor pendorong bagi karyawan untuk bekerja lebih baik agar kinerja karyawan dapat meningkat.Kompensasi dan insentif mempunyai hubungan yang sangat erat, dimana insentif merupakan komponen dari kompensasi dan keduanya sangat menentukan dalam pencapaian tujuan dan sasaran organisasi secara keseluruhan.

Siagian (2012:252) mengungkapkan bahwa : Kepentingan pekerja harus memungkinkannya untuk mempertahankan harkat dan martabatnya sebagai insan yang 
terhormat. Jadi kompensasi yang diterimanya dari bekerja dapat dipakai untuk hidup yang wajar dan layak, tanpa harus menggantungkan diri pada orang lain.

Menurut Hasibuan Melayu S.P (2013:118) menyatakan pengertian Insentif adalah tambahan balas jasa yang diberikan kepada karyawan tertentu yang prestasinya di atas prestasi standar. Upah insentif ini merupakan alat yang dipergunakan pendukung prinsip adil dalam pemberian kompensasi."

Menurut Mangkunegara (2011:89) menyatakan pengertian insentif adalah sebagai berikut: "Insentif adalah suatu bentuk uang yang diberikan oleh pihak pemimpin organisasi kepada karyawan agar mereka bekerja dengan motivasi yang tinggi dan berprestasi dalam mencapai tujuan-tujuan organisasi sebagai pengakuan prestasi kerja dan kontribusi karyawan kepada organisasi."

Dari beberapa pengertian insentif di atas maka jelaslah bahwa insentif merupakan penghargaan atau imbalan balas jasa yang diberikan kepada para karyawan atas kinerjanya yang melebihi standar. Pemberian insentif juga diharapkan dapat memotivasi dalam mencapai tujuan.

\section{Hipotesis}

Berdasarkan perumusan masalah dan kerangka konseptual maka peneliti menetapkan hipotesis di dalam penelitian ini yaitu:

1. Upah berpengaruh signifikan terhadap kinerja karyawan di PT. Milano Panai Tengah.

2. Insentif berpengaruh signifikan terhadap kinerja karyawan di PT. Milano Panai Tengah.

3. Upah dan Insentif secara bersama-sama berpengaruh positif dan signifikan terhadap Kinerja karyawan di PT. Milano Panai Tengah.

\section{METODE PENELITIAN}

\section{Populasi}

Menurut Sugiyono (2013: 117) populasi adalah generalisasi yang terdiri atas obyek/subyek yang mempunyai kualitas dan karakteristik tertentu yang ditetapkan oleh peneliti untuk dipelajari dan kemudian ditarik kesimpulannya.Populasi dalam penelitian ini adalah seluruh tenaga kerja pada PT. Milano Panai Tengah yang berjumlah sebanyak 137 orang.

\section{Sampel}

Menurut sugiyono (2013: 118) sampel adalah bagian dari jumlah dan karakteristik yang dimiliki oleh populasi tersebut.

Dalam penelitian ini metode yang digunakan dalam pengambilan sampel menggunakan rumus Slovin yaitu sebagai berikut :

dimana

$$
n=\frac{N}{1+N e^{2}}
$$

n : jumlah sampel

$\mathrm{N}$ : jumlah populasi

e : batas toleransi kesalahan (error tolerance) 
Jumlah sampel yang diperoleh penelitian ini dengan nilai populasi yang ditetapkan sebesar $10 \%$ adalah sebagai berikut :

$n=\frac{131}{1+131 x 0,10^{2}}=56,70$

Maka sampel dibulatkan menjadi 57 Orang. Sampel yang akan diambil dari populasi menggunakan conveniencesampling, yaitu istilah umum yang mencakup variasi luasnya prosedur pemilihan responden. Conveniencesampling merupakan pengumpulan informasi dari anggota populasi yang dengan senang hati bersedia memberikannya (Uma Sekaran, 2011:38).

\section{Analisis Regresi Linier Beraganda}

Metode analisis data yang digunakan dalam penelitian ini dengan mengumpulkan, mengolah, mengklasifikasikan dan menginterprestasikan data penelitian, sehingga diperoleh gambaran jelas mengenai objek yang diteliti dengan menggunakan Analisis Regresi Linier Berganda. Menurut Situmorang dan Lufti (2014 :166) mengemukakan analisis regresi linear berganda ditujukan untuk menentukan hubungan linear antar beberapa variabel independen yaitu Upah $\left(\mathrm{X}_{1}\right)$, dan Insentif $\left(\mathrm{X}_{2}\right)$ dengan variabel dependen yaitu Kinerja Karyawan $(\mathrm{Y})$.

Berdasarkan hubungan dua variabel yang dinyatakan dengan persamaan linear dapat digunakan untuk membuat prediksi (ramalan) tentang besarnya nilai Y (variabel dependen) berdasarkan nilai X tertentu (variabel independen). Ramalan (prediksi) tersebut akan menjadi lebih baik bila kita tidak hanya memperhatikan satu variabel yang mempengaruhi (variabel independen). Bentuk dari persamaan regresi linear berganda yang digunakan dalam penelitian ini dapat dirumuskan:

$$
\mathbf{Y}=\mathbf{a}+\mathbf{b}_{1} \mathbf{X}_{1}+\mathbf{b}_{2} \mathbf{X}_{2}+\mathbf{e}
$$

Keterangan:

Y = Kinerja KaryawanPT. Milano Panai Tengah Labuhanbatu

a $=$ Konstanta

$\mathrm{b}_{1}-\mathrm{b}_{2}=$ Koefisien Regresi

$\mathrm{X}_{1}=\mathrm{Upah}$

$\mathrm{X}_{2}=$ Insentif

e $\quad=$ Standard Error

\section{Uji Hipotesis}

Uji hipotesis yang digunakan dalam penelitian ini adalah uji signifikan parsial (uji t) dan simultan (uji f). Menurut Situmorang dan Lufti (2014: 172) yaitu:

\section{Uji Signifikan Parsial (Uji-t)}

Untuk menguji apakah hipotesis yang diajukan diterima atau ditolak digunakan statistik $\mathrm{t}$ (uji t). Pengujian ini dilakukan untuk mengetahui seberapa besar pengaruh variabel bebas yaitu Upah $\left(\mathrm{X}_{1}\right)$, Pengalaman Kerja $\left(\mathrm{X}_{2}\right)$ secara parsial terhadap variabel terikat yaitu Produktivitas Kerja Karyawan (Y). Bentuk pengujiannya sebagai berikut:

a) $\mathrm{H}_{0}: \mathrm{b}_{1}=0$, artinya secara parsial tidak terdapat pengaruh yang positif dari variabel bebas yaitu Upah $\left(\mathrm{X}_{1}\right)$, Insentif $\left(\mathrm{X}_{2}\right)$ secara parsial terhadap variabel terikat yaitu Kinerja Karyawan (Y).

b) $\mathrm{H}_{\mathrm{a}}: \mathrm{b}_{1} \neq 0$, artinya secara parsial terdapat pengaruh yang positif dari variabel bebas yaitu Upah $\left(\mathrm{X}_{1}\right)$, Insentif $\left(\mathrm{X}_{2}\right)$ secara parsial terhadap variabel terikat yaitu Kinerja Karyawan (Y).

Dengan kriteria pengambilan keputusan sebagai berikut: 
a) Jika $\mathrm{t}_{\text {hitung }}<\mathrm{t}_{\text {tabel }}$, maka $\mathrm{H}_{0}$ diterima atau $\mathrm{H}_{\mathrm{a}}$ ditolak.

b) Jika $\mathrm{t}_{\text {hitung }}>\mathrm{t}$ tabel, maka $\mathrm{H}_{0}$ ditolak atau $\mathrm{H}_{\mathrm{a}}$ diterima.

Jika tingkat signifikansi dibawah 0.05 maka $\mathrm{H}_{0}$ ditolak dan $\mathrm{H}_{\mathrm{a}}$ diterima.

\section{Uji Signifikan Simultan (Uji-F)}

Untuk menguji apakah hipotesis yang diajukan diterima atau ditolak digunakanstatistik F (uji F). Uji F bertujuan untuk mengetahui pengaruh secara serentak ataubersama-sama variabel bebasyaitu Upah $\left(\mathrm{X}_{1}\right)$, Insentif $\left(\mathrm{X}_{2}\right)$ terhadap variabel terikat yaitu Kinerja Karyawan (Y). Perumusan hipotesisnya yaitu:

a) Ho: $b_{1}=b_{2}=b_{3}=0$, artinya tidak terdapat pengaruh yang signifikan dari variabel-variabel bebas (independent variable) secara bersama-sama terhadap variabel terikat (dependent variable).

b) $\mathrm{H}_{\mathrm{a}}: \mathrm{b}_{1} \neq \mathrm{b}_{2} \neq \mathrm{b}_{3} \neq 0$, artinya terdapat pengaruh yang signifikan dari variabel-variabel bebas (independent variable) secara bersama-sama terhadap variabel terikat (dependent variable). Dengan kriteria pengambilan keputusan sebagai berikut:

a) Jika $\mathrm{F}_{\text {hitung }}<\mathrm{F}_{\text {tabel }}$, maka $\mathrm{H}_{0}$ diterima atau $\mathrm{H}_{\mathrm{a}}$ ditolak.

b) Jika $\mathrm{F}_{\text {hitung }}>\mathrm{F}_{\text {tabel, }}$ maka $\mathrm{H}_{0}$ ditolak atau $\mathrm{H}_{\mathrm{a}}$ diterima.

Jika tingkat signifikansi dibawah 0.05 maka $\mathrm{H}_{0}$ ditolak dan $\mathrm{H}_{\mathrm{a}}$ diterima.

\section{PEMBAHASAN}

\section{Hasil Pengujian Variabel Upah $\left(\mathrm{X}_{1}\right)$}

Pada kolom Coefficientsvariable Upah $\left(\mathrm{X}_{1}\right)$ mempunyai nilai thitung $(5,694)>\mathrm{t}_{\text {tabel }}$ (1.67356) yang berarti Ho ditolak dan Ha diterima. Sedangkan nilai signifikan lebih kecil dari nilai probabilitas 0,05 atau nilai signifikan $0,000<0,05$. Dengan demikian dapat disimpulkan variabel Upah $\left(\mathrm{X}_{1}\right)$ berpengaruh positif dan signifikan terhadap Kinerja Karyawan di PT Perkebunan Milano pada $\alpha=5 \%$. Artinya walaupun ditingkatkan variabel Upah sebesar satu satuan maka Produktivitas Kerja Karyawan akan meningkat sebesar 0,301 satuan.Nilai t positif menunjukkan bahwa variabel Upah mempunyai hubungan yang searah dengan Kinerja Karyawan.

\section{Hasil Pengujian Variabel Insentif $\left(\mathbf{X}_{2}\right)$}

Pada kolom Coefficientsvariabel Pengalaman Kerja $\left(\mathrm{X}_{2}\right) \mathrm{t}_{\text {hitung }}(\mathbf{2 , 4 2 2})>\mathrm{t}_{\text {tabel }}$ (1.67356) yang berarti Ho ditolak dan Ha diterima. Sedangkan nilai signifikan lebih kecil dari nilai probabilitas 0,05 atau nilai signifikan 0,000 $<0,05$. Dengan demikian dapat disimpulkan variable Pengalaman Kerja $\left(\mathrm{X}_{2}\right)$ berpengaruh positif dan signifikan terhadap Kinerja Karyawan di PT Perkebunan Milano pada $\alpha=5 \%$. Artinya jika ditingkatkan variabel Insentif sebesar satu satuan maka Kinerja Karyawan akan meningkat sebesar 0,771 satuan. Nilai t positif menunjukkan bahwa variabel Insentif hubungan yang searah dengan Kinerja Karyawan. Dengan demikian hipotesis diterima bahwa variabel Upah $\left(\mathrm{X}_{1}\right)$ dan Insentif $\left(\mathrm{X}_{2}\right)$ secara parsial mempengaruhi Kinerja Karyawan di PT Perkebunan Milano Panai Tengah.

\section{Hasil Uji F}

nilai $F_{\text {hitung }}$ adalah 22,485dengan tingkat signifikansi 0,000. Berdasarkan hasil uji $\mathrm{F}$ data penelitian ini adalah signifikan, dapat dilihat dari nilai sig lebih kecil dari nilai alpha $(0,000<$ $0,05)$. 
Menentukan kriteria pengambilan keputusanjika $\mathrm{F}$ hitung $<\mathrm{F}$ tabel , maka $\mathrm{H}_{0}$ diterima atau $\mathrm{H}_{\mathrm{a}}$ ditolak.Jika $\mathrm{F}$ hitung $>\mathrm{F}$ tabel, maka $\mathrm{H}_{0}$ ditolak atau $\mathrm{H}_{\mathrm{a}}$ diterima Dengan tingkat signifikansi dibawah 0.05 maka $\mathrm{H}_{0}$ ditolak dan $\mathrm{H}_{\mathrm{a}}$ diterima.

\section{KESIMPULAN}

Kesimpulan yang dirumuskan penulis berdasarkan perumusan masalah dalam penelitian ini adalah:

1. Pengujian secara parsial Upah berpengaruh signifikan terhadap Kinerja Karyawan di PT Perkebunan Milano Panai Tengah dengan nilai thitung $(2,422)>t_{\text {tabel }}(1.29743)$ yang berarti Ho ditolak dan Ha diterima.

2. Pengujian secara parsial Insentif berpengaruh signifikan terhadap Kinerja Karyawan di PT Perkebunan Milano Panai Tengah dengan nilai thitung $(6,114)>t_{\text {tabel }}(1.29743)$ yang berarti Ho ditolak dan Ha diterima.

3. Pengujian secara simultan Upah dan Insentif secara bersama-sama berpengaruh signifikan terhadap Kinerja Karyawan di PT Perkebunan Milano Panai Tengah dengan nilai $F_{\text {hitung } 22,422>} F_{\text {tabel } 3,17}$ yaitu Ha diterima dan Ho ditolak.

\section{SARAN}

Dalam penelitian ini, penulis memberikan saran kepada pihak-pihak yang berkepentingan pada penelitian ini, antara lain:

1. Sehubungan dengan Upah yang merupakan variabel dominan yang mempengaruhi Kinerja Karyawan di PT Perkebunan Milano Panai Tengah, maka untuk Perusahaan disarankan untuk memperhatikan dan meningkatkan karyawan yang menunjukan prestasi kerja pada perusahaan sehingga dapat dijadikan contoh teladan bagi karyawan yang lain bahwa pemberian upah yang layak dari perusahaan dapat meningkatkan Kinerja karyawan.

2. Bagi karyawan, insentif terbukti memberikan pengaruh yang signifikan terhadap kinerja mereka dalam bekerja. Oleh karena itu, karyawan hendaknya menjadikan insentif sebagai penyemangat dalam bekerja. Selain itu harus selalu memperhatikan atau bahkan meningkatkan motivasi, khususnya untuk memperoleh insentif yang lebih besar.

3. Bagi PT. Perkebunan Milano Panai Tengah hendaknya lebih memperhatikan karyawan, lebih memperhatikan hak-hak, memberikan kesejahteraan, dan sebagainya agar mereka lebih loyal dan memiliki kinerja yang tinggi.

4. Bagi peneliti-peneliti selanjutnya diharapkan dapat melakukan penelitian dengan menggunakan variabel yang berbeda dengan variabel yang diteliti dalam penelitian ini sehingga dapat memperoleh hasil yang lebih bervariatif yang dapat berpengaruh terhadap Kinerja Karyawan 


\section{DAFTAR PUSTAKA}

A.A. Anwar Prabu Mangkunegara. (2011). Manajemen Sumber Daya Manusia Perusahaan. Bandung : Rosda.

Bangun, Wilson. 2012. “Manajemen Sumber Daya Manusia”. Jakarta: Erlangga.

Desiana Dian, (2013) Judul "Pengaruh Insentif Terhadap Kinerja Karyawan Duta Catering -CV Darma Utara Batu.

Dessler, Gary, 2011. Manajemen sumber daya manusia. Penerbit Indeks, Jakarta

Firmansyah Zakaria (2015) judul penelitian "Analisis pengaruh Umur, Pendidikan, dan Upah Terhadap Produktivitas Tenaga Kerja Pada Mitra Kerja Industri Rambut di Kabupaten Purbalingga"

Handayani Dwi (2009) "Pengaruh Upah, Masa Kerja, dan Tunjangan Kesejahteraan Sosial Terhadap Produktivitas Karyawan pada PT. Widya Sapta Colas Bontang Kalimantan Timur”

Handoko, T. Hani. 2012. Manajemen Personalia dan Sumber Daya Manusia. Yokyakarta :BPFE

Hasibuan, Malayu S.P. 2010. Manajemen Sumber Daya Manusia. Jakarta: PT Bumi Aksara.

Hariandja, 2011. Manajemen Sumber Daya Manusia : Pengadaan, Pengembangan, Pengkompensasian, dan Peningkatan Produktivitas Pegawai. Jakarta : Grasindo.

Husnan SuadHeidjrahman. 2013 Pengaruh Upah Minimum Provinsidan alokasi Belanja pemerintah terhadap indeks pembangunan manusiaprovinsi Lampung. Skripsi. FEB Universitas Lampung

Justine T Sirait. 2010. Memahami Aspek-Aspek Pengelolaan Sumberdaya Manusia dalam Organisasi. Jakarta: PT. Grasindo.

Lufti danSitumorang, 2014. Analisis Data untuk Riset Manajemen dan Bisnis, USU Press, Medan.

Lutfi, Situmorang. 2014Metode Penelitian. Cetakan V Pustaka Pelajar:Yogyakarta

Mathis, Robert - H. Jackson, John., 2011. Human Resource Management (edisi 10). Jakarta : Salemba Empat. 
Nawawi. 2011. Manajemen Sumber Daya Manusia untuk yang Kompetitif. Yokyakarta : Gajah Mada Universitas Presh.

Nawawi Hadari . 2011. Analisis Pengaruh Pendidikan, Upah, Jenis Kelamin Usia, dan Pengalaman Kerja Terhadap Produktivitas Tenaga Kerja (Studi Di Industri Kecil Tempe Di Kota Semarang).

Rivai Viethzal. 2010. Manajemen Sumber Daya Manusia untuk Perusahaan Dari Teori ke Praktik. Jakarta : PT. Raja Grafindo Persada.

Sutrisno, Edy. 2013 Manajemen Sumber Daya Manusia, Edisi Pertama, Jakarta:kencana.

Sugiyono, 2013. Metode Penelitian Kuantitatif kualitatif dan R\&D, Alfabeta, Bandung. 